\title{
Article
}

\section{Water Erosion Monitoring and Prediction in Response to the Effects of Climate Change Using RUSLE and SWAT Equations: Case of R'Dom Watershed in Morocco}

\author{
Abdennabi Alitane 1,* Ali Essahlaoui ${ }^{1}$, Mohammed El Hafyani ${ }^{1}$ (D), Abdellah El Hmaidi ${ }^{1}$ (D), Anas El Ouali ${ }^{2}$ (D) \\ Amina Kassou ${ }^{3}$, Yassine El Yousfi ${ }^{4}$, Ann van Griensven ${ }^{5,6}$, Celray James Chawanda ${ }^{6}$ D \\ and Anton Van Rompaey ${ }^{7}$ (D)
}

check for updates

Citation: Alitane, A.; Essahlaoui, A.; El Hafyani, M.; El Hmaidi, A.; El Ouali, A.; Kassou, A.; El Yousfi, Y.; van Griensven, A.; Chawanda, C.J.; Van Rompaey, A. Water Erosion Monitoring and Prediction in Response to the Effects of Climate Change Using RUSLE and SWAT Equations: Case of R'Dom Watershed in Morocco. Land 2022, 11, 93 https://doi.org/10.3390/land 11010093

Academic Editor:

Manuel López-Vicente

Received: 17 November 2021

Accepted: 2 January 2022

Published: 7 January 2022

Publisher's Note: MDPI stays neutral with regard to jurisdictional claims in published maps and institutional affiliations.

Copyright: (c) 2022 by the authors Licensee MDPI, Basel, Switzerland. This article is an open access article distributed under the terms and conditions of the Creative Commons Attribution (CC BY) license (https:// creativecommons.org/licenses/by/ $4.0 /)$
1 Geoengineering and Environment Laboratory, Research Group “Water Sciences and Environment Engineering", Geology Department, Faculty of Sciences, Moulay Ismail University, Presidency, Marjane 2, Meknes BP 298, Morocco; A.ESSAHLAOUI@fs-umi.ac.ma (A.E.); m.elhafyani@edu.umi.ac.ma (M.E.H.); a.elhmaidi@umi.ac.ma (A.E.H.)

2 Functional Ecology and Environmental Engineering Laboratory, Faculty of Science and Technology, Sidi Mohamed Ben Abdellah University, Fez BP 262, Morocco; anas.elouali@usmba.ac.ma

3 Geo-Resource, Geo-Environment and Oasis Geological Heritage Research Group, Engineering Sciences and Techniques Laboratory, Geosciences Department, Faculty of Sciences and Techniques, Moulay Ismail University, Presidency, Marjane 2, Meknes BP 298, Morocco; kassou.amina@gmail.com

4 Water and Environment Management Group, Civil Engineering and Environment Department, National School of Applied Sciences Al Hoceima, Abdelmalek Essaadi University, Tangier BP 211, Morocco; yassine.elyousfi@etu.uae.ac.ma

5 Water Resources and Ecosystems Department, IHE Delft Institute for Water Education, 2611 AX Delft, The Netherlands; Ann.Van.Griensven@vub.be

6 Hydrology and Hydraulic Engineering Department, Vrije Universiteit Brussels (VUB), 1050 Brussels, Belgium; celray.chawanda@vub.be

7 Geography and Tourism Research Group, Earth and Environmental Science Department, KU Leuven, Celestijnenlaan 200E, 3001 Heverlee, Belgium; anton.vanrompaey@kuleuven.be

* Correspondence: abdennabi.alitane@edu.umi.ac.ma

Abstract: Soil erosion is an increasingly issue worldwide, due to several factors including climate variations and humans' activities, especially in Mediterranean ecosystems. Therefore, the aim of this paper is: (i) to quantify and to predict soil erosion rate for the baseline period (2000-2013) and a future period (2014-2027), using the Revised Universal Soil Loss Equation (RUSLE) and the Soil and Water Assessment Tool (SWAT) model in the R'Dom watershed in Morocco, based on the opportunities of Remote Sensing (RS) techniques and Geographical Information System (GIS) geospatial tools. (ii) we based on classical statistical downscaling model (SDSM) for rainfall prediction. Due to the lack of field data, the model results are validated by expert knowledge. As a result of this study, it is found that both agricultural lands and bare lands are most affected by soil erosion. Moreover, it is showed that soil erosion in the watershed was dominated by very low and low erosion. Although the area of very low erosion and low erosion continued to decrease. Hence, we hereby envisage that our contribution will provide a more complete understanding of the soil degradation in this study area and the results of this research could be a crucial reference in soil erosion studies and also may serve as a valuable guidance for watershed management strategies.

Keywords: soil erosion; RUSLE; SWAT; classical statistical downscaling model; remote sensing; GIS tools; R'Dom watershed

\section{Introduction}

Soil degradation is a form of soil loss that involves the detachment, transport, sedimentation and deposition of soil from one area to another by the forces of dynamics and the actions of erosive agents (water, ice, snow, air, plants, animals and humans [1]). 
Several factors including human activities and climatic variations such as topography, land cover and management, soil properties, and climate can contribute directly or indirectly in increasing the amount of degraded soil at the catchment scale. It is noted that the effects of climate change due to increased precipitation and temperature, and land use change due to human activities can lead to an activation of erosion processes [2]. This phenomenon is a worldwide environmental problem, that seriously threatens natural resources such as soil fertility, drainage and siltation [3]. It also contributes to the reduction of reservoir capacity and negatively affects aquatic habitats, hydrological systems and downstream water quality because of sediments that are generally charged with nutrients, toxic chemicals and metals [4]. In overall, soil erosion has severe effects on soil and water resources leading to the earth ecosystems disequilibrium.

An estimation of 33\% of the world's land area is classified as moderately to highly degraded because of several factors including erosion, salinization, compaction, acidification [5]. The costs of land degradation show an uncertainty in the global economic impact (ranged from 40 to 490 billion US\$) that varies across countries [6]. The United Nations' (UN) stated that " ... soils constitute the foundation for agricultural development, essential ecosystem functions and food security and hence are key to sustaining life on Earth" [7]. Moreover, the protection of the soil has received considerable interest among the 17 UN Sustainable Development Goals (SDGs) [8].

Soil erosion is an increasingly issue worldwide, more particularly in the Mediterranean regions, known as "hot-spot" of climate change because of water scarcity [9]. Morocco, as one of the Mediterranean countries, is highly experienced to severe episodic drought and characterized by extreme natural inter-annual variability, spatial and temporal heterogeneity of precipitation [10], seasonality of water resources and decreasing river flows [11].

The assessment of eroded areas based on field missions monitoring is a challenging and time-consuming task because it is difficult to be applied to broad extensions [12]. To overcome this limitation, many different models are used and developed to quantify soil erosion. These approaches are divided into empirical and physically-based models [13]. Empirical models are easy to be used in areas where the availability of data and parameters is limited, these include Universal Soil Loss Equation (USLE) [14] and its revised version Revised Universal Soil Loss Equation (RUSLE) [15], Modified Universal Loss Equation (USLE Modified) [16], Erosion Potential Method (EPM) [17], and SEdiment DElivery Distributed (SEDD) Model [18]. Physically-based models, require a good knowledge of the physics of the hydrological processes. These include, Soil and Water Assessment Tool (SWAT) [19], Watershed Erosion Prediction Project (WEPP) [19], Agricultural Non-Point Source Pollution (AGNPS) model [20], Areal Non-point Source Watershed Environment Response Simulation (ANSWERS) model [21], Limburg Soil Erosion Model (LISEM) [22], European Soil Erosion Model (EUROSEM) [23], Soil Erosion Model for Mediterranean Regions (SEMMED) [24], Simulator for Water Resources in Rural Basins (SWRRB) [25], MMF (Morgan-Morgan-Finney) model [26], and the Hydrologic Simulation Program-FORTRAN (HSPF) [27].

Due to its severity, gully erosion considered as the major type of water erosion, has become a growing interest of many researchers Therefore, a large number of methods have been used in the mapping of gully erosion susceptibility based on the study of the relationship between a set of independents variables (conditioning factors) and target variable (i.e., presence/absence of gully erosion), including for example, maximum entropy model (MaxEnt) [28], Analytical Hierarchy Process (AHP) model [29], Evidential Belief Function (EBF) [30], Frequency Ratio (FR) [31], and Classification and Regression Trees (CART) [32].

Numerous studies in the literature have used RUSLE equation and SWAT model with successful contributions (see for e.g., [33-35]). Also, in Morocco, Boufala, M'hamed, et al. [36] used the SWAT model in the Upper Sebou watershed to monitor and quantify the soil losses.Their results showed that the annual soil loss can reach a maximum value (more than $12.11 \mathrm{tha}^{-1}$ ) at the upstream of the basin and a minimum value (less than $4 \mathrm{t} \mathrm{ha}^{-1}$ ) and the 
siltation rate of the retention dam was estimated at $2.12 \mathrm{~mm} /$ year. The same authors reported that the soil degradation is due to the physical basin properties. In another research, Boufala M'hamed, et al. [37] applied both RUSLE equation and SWAT model for the assessment of soil erosion in the $\mathrm{M}^{\prime}$ dez watershed in Morocco, reporting that the results obtained are similar for both the approaches, with an estimation of soil degradation at $3.95 \mathrm{tha}^{-1}$ when considering SWAT model, and an estimation of soil degradation at $2.94 \mathrm{tha}^{-1}$ based on RUSLE equation. Khalid [38] conducted a study in the Sebou watershed (Morocco) to quantify soil degradation due to erosion using RUSLE equation. The results showed that the erosion in this basin is influenced by topography, rainfall, soil properties, crop management conditions, and conservation practices. In the same study, the results showed that $78.83 \%$ of the study area has a low risk of erosion, $17.36 \%$ a medium risk, $3.04 \%$ a high risk and $0.77 \%$ a very high risk.

Currently, there is no "best model" for erosion risk mapping as claimed by Abdelwahab, et al. [12]. Moreover, the same authors highlighted that, model performance depends on the background of the model, the required data, the equations used to formalize the processes and the results provided.

Although RUSLE model was developed to estimate water erosion in mild climate, it is easier to adjust for tropical climate than other models. It is prepared to apply at the runoff plot or single hillslope scales, allows the estimation of average annual rate of soil erosion for a specific area for identifying targeting management interventions or practices, cropping systems and erosion control practices. The RUSLE model computes the expected average annual soil loss on hillslopes by multiplying five factors together namely [39]: rainfall erosivity $(\mathrm{R})$, cover management $(\mathrm{C})$, slope length and slope steepness (LS), soil erodibility (K), and support practice (P).

The SWAT model is a semi-distributed, time-continuous hydrologic model generally applied at the watershed scale to simulate surface water and groundwater quality and quantity [40]. This model works with hydrological response units (HRUs) which are areas with unique characteristics identified by land use, soil type, and slope, and then the calculations at the HRU level will be channeled through stream connections to the basin outlet. The estimation of soil loss in the SWAT model is based on the Modified Universal Soil Loss Equation (MUSLE) [41].

When it comes to handling and processing different and large spatial data, it is necessary to use RS and GIS tools because of their great opportunities provided [42]. These opportunities include (and not restrict to specific operations); processing, editing, and analysis of the required input factors for soil erosion mapping. Therefore, RS data and GIS tools play an interesting role in soil erosion monitoring through the exploitation of different satellite images and geospatial analyses ([43]. Therefore, for the present study, the RUSLE and SWAT models using RS and GIS tools were applied.

To the best of authors' knowledge, no previous research has been carried out that explores the combination of these two approaches in this study area. Indeed, the novelty of this paper is the exploitation of the advantages of these two models. Therefore, the objective of this work is, (i) to map and to monitor the soil erosion degradation in the R'Dom watershed using SWAT and RUSLE models; and (ii) to predict the annual variation of soil losses due to the effects of climate change variations through the application of statistical downscaling method. We hereby envisage that our contribution will provide a more complete understanding of the soil degradation in this study area and could be a good reference for decision planning strategies.

\section{Materials and Methods}

\subsection{Study Area}

The $\mathrm{R}^{\prime}$ Dom river watershed is located in the northwestern part of Morocco between longitudes $5.29^{\circ}$ and $5.75^{\circ} \mathrm{W}$ and latitudes $33.47^{\circ}$ and $34.01^{\circ} \mathrm{N}$ (Figure 1 ) covering an area of $1970 \mathrm{~km}^{2}$. The watershed has a maximum elevation of $1778 \mathrm{~m}$ at the southern end and minimum elevation of $29 \mathrm{~m}$ at the outlet. The current study area is characterized by a 
semi-arid climate, with an average annual precipitation of $474.4 \mathrm{~mm}$, with a dry period ranging from May to mid-September [44]. 44\% of the rainiest seasons are winter, whereas $25 \%$ are spring, while the average annual temperature is $17.6^{\circ} \mathrm{C}$ with January as the coldest month and August as the warmest month. In terms of hydrology, the basin consists of the main river, Oued R'Dom and its affluent rivers (Boufakrane, Ouislane, Chajara, Ishak, Sidi Ali, Frah and Khoumane). According to [45], the hydrogeological system of the watershed is composed of two main aquifers units, the deep aquifer and the Plio-Quaternary aquifer. From a geological point of view, the study area is essentially filled by a deep series of blue marls of Tortonian age followed by Pliocene fauvist sands and conglomerates and lacustrine limestone of Plio-Quaternary era. The dominant crops in the study area are rainfed cereals, sunflower, onion and olive trees (45\% of total surface of the watershed) [46], in addition to forest and pasture lands. The main economic activity in this study area is agriculture, and the use of water resources has increased, leading to an unsustainable agriculture, hence contribute to land degradation in this watershed. Therefore, it is urgently needed to develop adaptation practices and strategies to cope with soil degradation.
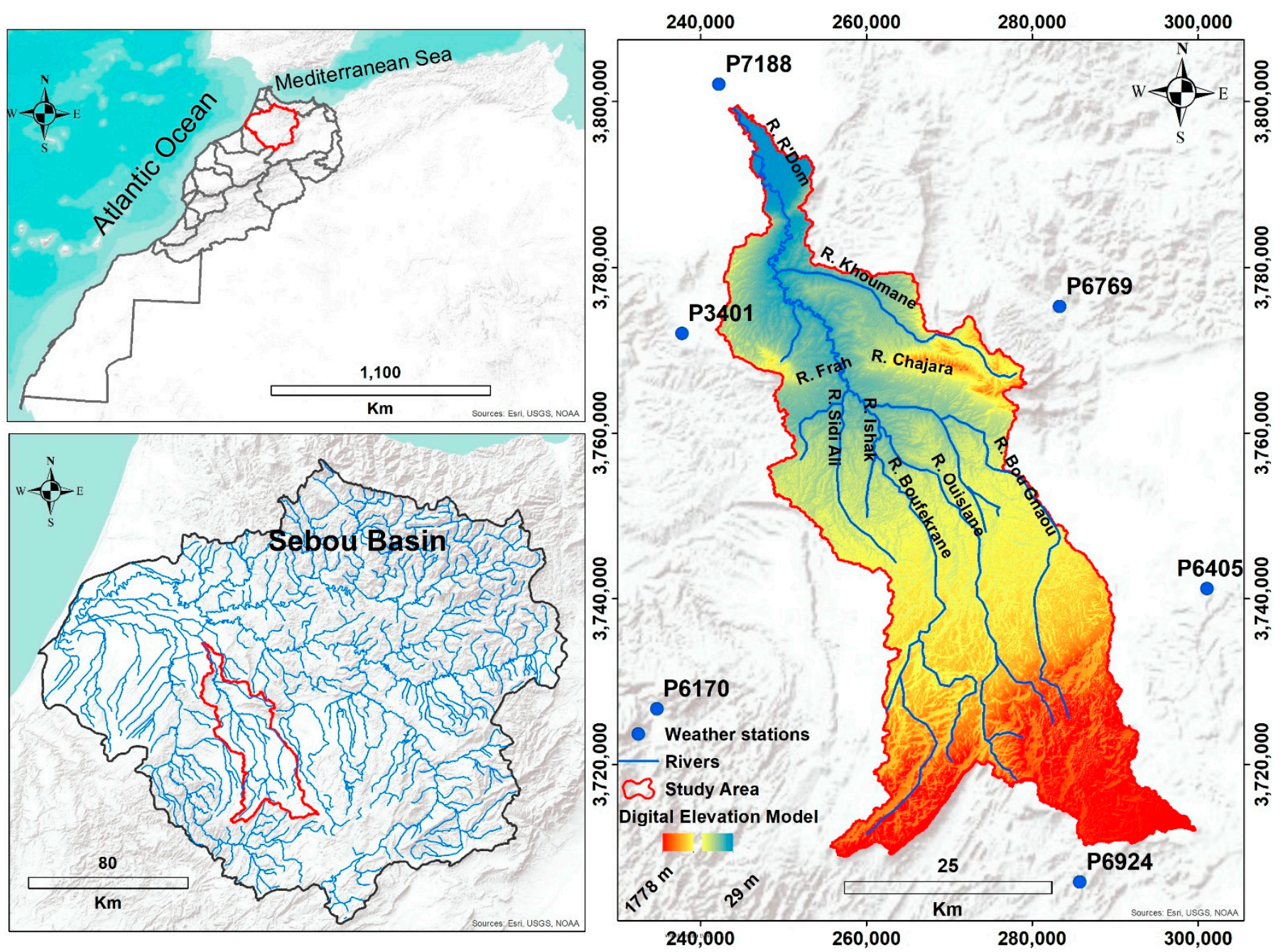

Figure 1. Location of the study area.

\subsection{Data Used and Methodology}

In order to carry out the current research reported in this manuscript, we used several data given in Table 1. It should be mentioned that all data used are resampled to the Sentinel 2A spatial resolution $(10 \mathrm{~m})$ based on the nearest neighbor algorithm.

More details are given below. 
Table 1. Data used in this research.

\begin{tabular}{|c|c|c|c|}
\hline Data & Spatial Resolution & Coordinate System & Source \\
\hline Digital Elevation Model (DEM) & $30 \mathrm{~m}$ & UTM/WGS84 ${ }^{1}$, Zone $30 \mathrm{~N}$ & {$[47]$} \\
\hline Land cover Map & $10 \mathrm{~m}$ & UTM/WGS84 ${ }^{1}$, Zone $30 \mathrm{~N}$ & {$[47]$} \\
\hline Soil data & $30 \mathrm{~m}$ & UTM/WGS84 ${ }^{1}$, Zone $30 \mathrm{~N}$ & Field collection/reports \\
\hline Climate data & $30 \mathrm{~m}$ & UTM/WGS84 ${ }^{1}$, Zone $30 \mathrm{~N}$ & Sebou Hydraulic Basin Agency (SHBA) \\
\hline
\end{tabular}

${ }^{1}$ World Geodetic System (WGS84) datum and the Universal Transverse Mercator (UTM) projection system.

\subsubsection{Sentinel-2 Images}

In this study, one sentinel-2A image acquired on 24 June 2016, composed of 13 spectral bands in the VNIR and SWIR with spatial resolutions ranging from 10 to 60 was used for producing Land use/Land cove map. The image was downloaded free of charge from website [47]. The image was acquired during the dry season due to minimal cloud coverage (less than 10\%).

The image was preprocessed in QGIS software version 3.22 using the developed plugin Semi-Automatic Classification Plugin (SCP), developed by Luca Congedo [48] The processing was done following various steps including: the conversion of the digital number (DN) to top-of-atmosphere reflectance (TOA) and the subsequent atmospheric correction by the dark object subtraction (DOS) algorithm [49]. Sentinel-2A/B images have been successfully used for several environmental applications including land use/land cover mapping [50].

\subsubsection{Digital Elevation Model (DEM)}

Advanced Spaceborne Thermal Emission and Reflection Radiometer (ASTER) Global Digital Elevation Model (GDEM) was downloaded from the U.S. Geological Survey website [51]. This digital elevation model was used to extract slope length (L) and slope steepness (S).

\subsubsection{Soil Data}

In order to determine the physical and chemical characteristics of the soil such as texture, apparent density, permeability, structure and organic matter, soil sampling was carried out in the field, and the physical and chemical analyses were performed in the laboratory. In this study area, the most dominant soils are calcimagnesic soils with a percentage of $24 \%$, followed by raw mineral soils with $20 \%$, vertisoils with $18 \%$, poorly developed soils with $14 \%$, fersiallitic soils $13 \%$ and isohumic soils $11 \%$.

\subsubsection{Climatic Data}

Daily, monthly and annual rainfall data for the period from 1 September 2000 to 31 August 2013 for six stations located in the study area were used in this work. Then, the Statistical DownScaling Model (SDSM) has been used to predict future climate related to various Representative Concentration Pathway (RCP) scenario RCP 4.5.This method allows the downscaling of the most important climate variables, such as temperature, precipitation, evaporation, in order to assess hydrological responses under climate change scenarios [52].

\subsection{Methodology Adopted}

The estimation of soil erosion was performed using two approaches, the first is based on the application of the RUSLE equation and the second is based on the application of the SWAT model which is based on the MUSLE model for estimating sediment yields [53]. The climatic data were used to calculate the rainfall erosivity factor (R). The available geological data and the sampled soil properties were used to estimate the erodibility factor $(\mathrm{K})$ and the map of soil classes was used in SWAT model. The two factors of slope length (L) and slope steepness (S) were estimated from the DEM, and calculated by the LS factor tool (LS-TOOL) 
developed by [54].The sentinel satellite image was used for producing land cover/land use and to estimate Normalized Difference Vegetation Index (NDVI) used for the elaboration of the cover and management map served as input for both RUSLE equation and SWAT model. All the used factors in this study were calculated using ArcGIS software with a pixel size of $10 \mathrm{~m}$ and a coordinate system (WGS84 Zone 30N). The methodology developed in this research for RUSLE equation and SWAT model is presented in Figure 2. To generate the soil loss maps for both the studies periods, using both RUSLE equation and SWAT model, natural break classification technique, available in ArcGIS 10.5, was used to classify the soil losses into 5 classes, named, very low, low, moderate, high and very high. All layers were developed in GIS environment with a spatial resolution of $10 \mathrm{~m}$.

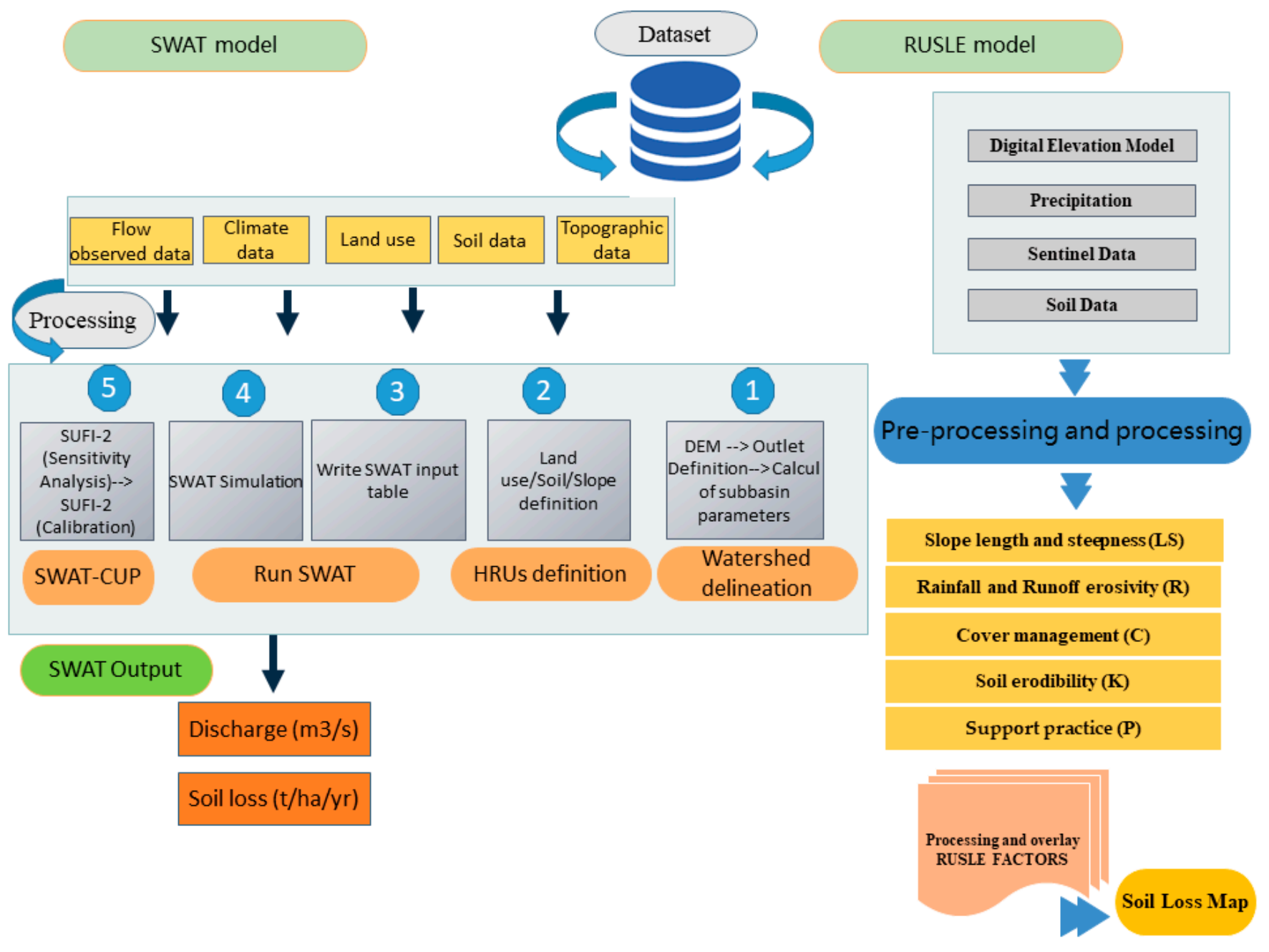

Figure 2. Methodology performed in the study.

\subsubsection{RUSLE Equation}

The application of the RUSLE equation requires the preparation of several maps of the different factors involved: rainfall erosivity $(\mathrm{R})$, cover and management $(\mathrm{C})$, slope length and slope steepness (LS), soil erodibility (K), and support practice (P) according to the Equation (1):

$$
A=R \times C \times L \times S \times K \times P
$$

where:

$A$ is the computed average soil loss over a period selected for $R$, usually on yearly basis $\left(\mathrm{tha}^{-1} \mathrm{y}^{-1}\right)$;

$R$ is the rainfall-runoff erosivity factor (MJ $\mathrm{mm} \mathrm{ha}^{-1} \mathrm{~h}^{-1} \mathrm{y}^{-1}$ ); 
$K$ is the soil erodibility factor ( $\mathrm{t}$ ha h ha ${ }^{-1} \mathrm{MJ}^{-1} \mathrm{~mm}^{-1}$ );

$L S$ is the slope length (L) and slope gradient (S) factor (dimensionless);

$C$ is the cropping management factor (dimensionless, ranging between 0 and 1 );

$P$ is the supporting conservation practice factor (dimensionless, ranging between 0 and 1 ).

A. Rainfall and Runoff erosivity factor (R)

The R-factor represents the erosive force of a specific rainfall [55]. It is calculated from the rainfall energy $E$ and the maximum rainfall intensity during a 30-min period (I30) using the Equation (2) developed by [56]:

$$
\mathrm{R}=\mathrm{E} \times \mathrm{I} 30 \text { and } \mathrm{E}=210+89 \log 10 \times \mathrm{I}
$$

where:

E: kinetic energy of rains (MJ/ha)

I30: maximum rainfall intensity in $30 \mathrm{~min} \mathrm{~mm} / \mathrm{h}$

I: rain intensity

The equation proposed by [56] is difficult to calculate, especially in areas where rainfall data are not regular or where detailed climatic data are not available. To overcome this limitation, many other empirical formulas are used by several authors especially for Mediterranean countries and in semiarid areas, where large uncertainties remain due to a lack of a high-resolution rainfall [57]. In their paper, Petroselli et al. [58] present 12 formulas, widely applied in Mediterranean areas. Therefore, in our study, this factor has been calculated using the Renard and Freimund equation which relates $\mathrm{R}\left(\mathrm{MJ} \mathrm{mm} \mathrm{ha} \mathrm{h}^{-1} \mathrm{~h}^{-1} \mathrm{y}^{-1}\right.$ ) to the average annual rainfall (P) (Equation (3)) [59].

$$
\mathrm{R}=0.0483 \times \mathrm{P}^{1.610} \text { If } \mathrm{P}<850 \mathrm{~mm}
$$

where:

$\mathrm{R}$ is the rainfall-runoff erosivity factor (MJ mm ha ${ }^{-1} \mathrm{~h}^{-1} \mathrm{y}^{-1}$ )

$P$ is the average annual rainfall $(\mathrm{mm})$

Table 2 shows the $\mathrm{R}$ factor values for the different stations used in this study.

Table 2. Monitoring and prediction annual average rainfall and R Factor of R'Dom watershed.

\begin{tabular}{ccccccc}
\hline & \multicolumn{2}{c}{ Co00/2013 } & \multicolumn{2}{c}{ 2014/2027 } \\
\hline \multirow{2}{*}{$\begin{array}{c}\text { Station } \\
\text { Name }\end{array}$} & $\mathbf{X}$ & $\mathbf{Y}$ & $\begin{array}{l}\text { Average } \\
\text { Rainfall }\end{array}$ & $\mathbf{R}$ & $\begin{array}{l}\text { Average } \\
\text { Rainfall }\end{array}$ & $\mathbf{R}$ \\
\cline { 2 - 7 } P3401 & 237,745 & $3,772,098$ & 395.30 & 732.82 & 497.69 & 1061.82 \\
\hline P6170 & 234,726 & $3,726,750$ & 488.72 & 1031.18 & 543.69 & 1224.24 \\
\hline P6405 & 301,106 & $3,741,223$ & 529.02 & 1171.49 & 695.13 & 1818.33 \\
\hline P6769 & 283,324 & $3,775,316$ & 467.92 & 961.44 & 501.92 & 1076.38 \\
\hline P6924 & 285,738 & $3,705,901$ & 615.66 & 1495.50 & 792.65 & 2246.3 \\
\hline P7188 & 242,214 & $3,802,127$ & 373.58 & 669.09 & 390.67 & 719.06 \\
\hline
\end{tabular}

In this work, we used the inverse distance weighting (IDW) spatial interpolation method available in ArcGIS software version 10.4 for presenting the spatial distribution for the rainfall data used. Then, the Statistical DownScaling Model (SDSM) was used to predict future climate for the period 2014-2027 related to various Representative Concentration Pathway (RCP) scenario RCP 4.5. Rainfall data were used to calculate the R-factor based on both Equations (2) and (3). 


\section{B. Soil erodibility factor $(\mathrm{K})$}

The soil erodibility factor $(\mathrm{K})$ is a factor that has an important influence in the RUSLE equation. It is directly related to soil and/or geological characteristics, such as parent material, texture, structure, organic matter content and porosity. This parameter was calculated using Equation (4) [56]:

$K=\left[27.66 m^{1.14} \times 10^{-8} \times(12-\mathrm{OM})\right]+[0.0043 \times(\mathrm{S}-2)]+[0.0033 \times(\mathrm{P}-3)] \times 0.1317$

where:

$K$ is the soil erodibility factor ton ha hr ha ${ }^{-1} \mathrm{MJ}^{-1} \mathrm{~mm}^{-1}$,

$m$ is the $($ silt $\%+$ sand $\%) \times(100-$ clay $\%)$,

$\mathrm{OM}$ is the \% organic matter,

$S$ is the structure code: (1) very structured or particulate, (2) fairly structured, (3) slightly structured, and (4) solid,

P is the profile permeability code: (1) rapid, (2) moderate to rapid, (3) moderate, (4) moderate to slow, (5) slow and (6) very slow.

Unfortunately, there is no detailed soil map available for the study area. In our case, we used the map generated by the Regional Institute of Agronomic Research (RIAR) to identify homogeneous units. A total number of 25 soil samples were taken from these units (0-25 cm deep), and the physical and chemical soil properties were carried out in the laboratory (NF P 94-056) to determine the main soil properties influencing the K factor such as, soil texture, organic matter, and soil structure. We computed the $\mathrm{K}$ factor as suggested by [56]. soil types in this study were determined according to Commission de Pédologie et de Cartographie des Sols (CPCS) [60]. The results of soil properties are summarized in Table 3 and Figure 3.

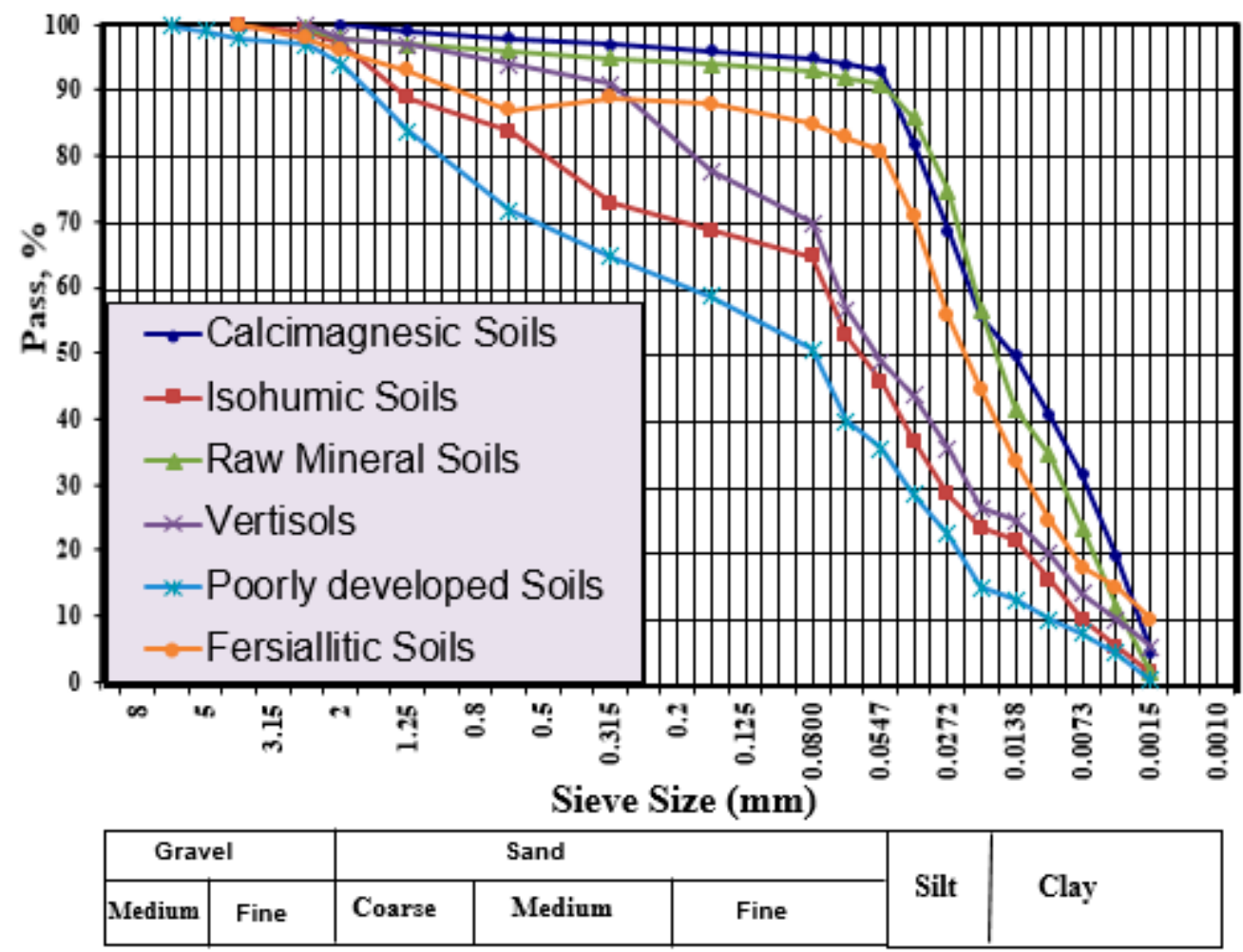

Figure 3. Particle Size Distribution Curve. 
Table 3. Soil characteristics of study area.

\begin{tabular}{cccccc}
\hline Soil Type & $\begin{array}{c}\text { Sand (\%) } \\
(\mathbf{0 . 0 5}-\mathbf{2} \mathbf{~ m m )}\end{array}$ & $\begin{array}{c}\text { Silt } \mathbf{( \% )} \\
\mathbf{( 0 . 0 2 - 0 . 0 5} \mathbf{~ m m )}\end{array}$ & $\begin{array}{c}\text { Clay (\%) } \\
(<\mathbf{0 . 0 2} \mathbf{~ m m )}\end{array}$ & $\begin{array}{c}\text { Organic } \\
\text { Matter (\%) }\end{array}$ & K-Factor \\
\hline Calcimagnesic Soils & 7.3 & 37.7 & 55 & 2.16 & 0.031 \\
Isohumic Soils & 55.7 & 21.1 & 24 & 1.07 & 0.062 \\
Raw Mineral Soils & 8.8 & 34.5 & 56.1 & 2.62 & 0.025 \\
Vertisols & 53.8 & 19.3 & 27.1 & 1.62 & 0.052 \\
Poorly developed Soils & 63.7 & 20.8 & 15.5 & 2.51 & 0.062 \\
Fersiallitic Soils & 18.6 & 36.2 & 45.2 & 1.63 & 0.045 \\
\hline
\end{tabular}

C. Slope Length and Steepness factor (LS)

The LS factor is very important, affecting sediment production and transport, compaction and soil disturbance. For the generation of LS factor, we used DEM to calculate flow accumulation and slope steepness using the spatial analyst tool and ArcHydro availaible in ArcGIS 10.4 .

The LS in this study was calculated using the Equation (5) developed by [61]:

$$
\mathrm{LS}=\left(\left(\frac{\text { "FlowAcc_flow" } \times 30}{22.1}\right)^{\mathrm{NN}}\right) \times(0.065+0.045 \times \text { "Slope" } \times \text { “Slope" })
$$

where NN represent dimensionless exponent that assumes the value of $0.2-0$.

D. Cover management factor $(C)$

The cover-management factor $(C)$ is used to describe the effect of crop management practices on erosion rates. The $\mathrm{C}$ factor was determined based on the NDVI index following the Equation (6) developed by [62]:

$$
C=0.431-(0.805 \times N D V I)
$$

The NDVI was developed for the first time by Rouse Jr. et al. [63], representing a good indicator for monitoring of vegetation activity. NDVI was calculated based on the reflectance between the infrared and red portions of the electromagnetic spectrum using the Equation (7):

$$
\mathrm{NDVI}=\frac{\mathrm{NIR}-\mathrm{R}}{\mathrm{NIR}+\mathrm{R}}
$$

where NIR is the near-infrared reflectance, and $\mathrm{R}$ is the reflectance in the red band. NDVI values varies between -1 and 1 .

E. Support practice factor $(\mathrm{P})$

According to [64], the factor $P$ is defined as the ratio of soil loss with a specific support practice to the corresponding loss with up slope and down slope tillage. The value of $P$ factor is determined based on the types of soil conservation measures. Thus, in this study, we determined the value of $\mathrm{P}$ factor based on the methodology recommended by Wischmeier and Smith [56]. For this purpose, sentinel 2A image was used to prepare the LULC map using the maximum likelihood classification algorithm. In total, eight LULC classes were established including: WATER (water), RNGE (Range-Grassess), FRST (Forest), WETN (Wetlands-non-Forsted), AGRL (agricultural Land-Generic), BARR (Barren), URHD (Residential-High Density), and UIDU (Industrial). Next, we reclassified the land cover/land use of the study area into two groups: "agricultural areas and other classes". After that, we classified the agricultural areas into 5 classes based on the slope, and then we assigned for each class of agricultural a P value and for all other classes we assigned 1, as can be seen in Table 4 . 
Table 4. $\mathrm{P}$ factor for different land use / land cover based on slope gradient [38].

\begin{tabular}{ccc}
\hline Land Use Class & Slope (\%) & P Factor Values \\
\hline \multirow{3}{*}{ Agricultural area } & $0-4$ & 0.5 \\
\cline { 2 - 3 } & $4-12$ & 0.6 \\
\cline { 2 - 3 } & $12-20$ & 0.7 \\
\cline { 2 - 3 } & $20-25$ & 0.8 \\
\hline Other land & $>52$ & 0.9 \\
\hline
\end{tabular}

Table 5 presents the error matrix, along with the overall accuracy (OA) and the Kappa coefficient. The OA of the classification was $80 \%$ and the Kappa coefficient was $76.8 \%$.

Table 5. Accuracy assessment for supervised classification of Sentinel image 2016.

\begin{tabular}{|c|c|c|c|c|c|c|c|c|c|}
\hline & WATER & FRST & RNGE & WETN & AGRL & BARR & URHD & UIDU & User Accuracy \\
\hline WATER & 127 & 2 & 1 & 23 & 2 & 0 & 0 & 0 & 81.93 \\
\hline FRST & 1 & 230 & 13 & 8 & 2 & 1 & 8 & 2 & 86.79 \\
\hline RNGE & 0 & 35 & 159 & 3 & 19 & 2 & 0 & 8 & 70.35 \\
\hline WETN & 8 & 0 & 2 & 56 & 0 & 0 & 2 & & 82.35 \\
\hline AGRL & 1 & 6 & 0 & 0 & 72 & 7 & 4 & 2 & 78.26 \\
\hline BARR & 2 & 0 & 0 & 0 & 1 & 66 & 3 & 9 & 81.48 \\
\hline URHD & 5 & 0 & 0 & 0 & 0 & 0 & 276 & 11 & 94.52 \\
\hline UIDU & 2 & 7 & 0 & 3 & 5 & 18 & 26 & 54 & 46.95 \\
\hline Producer Accuracy & 86.98 & 82.14 & 90.85 & 60.21 & 71.28 & 70.21 & 86.52 & 62.79 & $\begin{array}{c}\mathrm{OA}=0.80 \% \\
\text { Kappa index }=76.8\end{array}$ \\
\hline
\end{tabular}

\subsubsection{SWAT Model}

The SWAT model is a semi-distributed, time-continuous hydrological model, generally applied at the catchment scale. It allows the simulation of surface and groundwater quality and quantity, and also allows the prediction of the effect of field management practices on sediment, water and agricultural chemicals in large complex catchments with soils [65]. In addition, this model also allows the calculation of the simulated daily water balance based on the Equation (8) [65]:

$$
S W t=S W 0+\sum_{i=1}^{t}(R-Q \operatorname{surf}-E a-W r c h r g-Q l a t)_{i}
$$

where:

$S W t$ is the final soil water content $(\mathrm{mm})$, SW0 is the initial soil water content $(\mathrm{mm})$, $t$ is the time (days),

$R$ day is the amount of precipitation on day $i(\mathrm{~mm})$,

Qsurf is the amount of surface runoff on day $i(\mathrm{~mm})$,

$E a$ is the amount of evapotranspiration on day $i(\mathrm{~mm})$,

Wseep is the amount of water entering the vadose zone from the soil profile on day $i(\mathrm{~mm})$, Qlat is the amount of return flow on day $i(\mathrm{~mm})$.

The estimation of soil erosion rate by SWAT was based on the application of MUSLE (Equation (9)). It is a modified equation of USLE of which the rainfall energy factor is replaced with a runoff factor and uses the soil characteristic to calculate the runoff erosive energy variable. For the land use factor, it was performed from the processing of the sentinel-2 image by a supervised classification approach. The DEM was use to derive the factors relating to the morphology and the soil map was ranked according to the physical characteristics such as soil texture, humidity or water availability capacity (AWC), soil 
depth, rock fragments, organic material (OM), hydraulic conductivity ( $\mathrm{K}$ factor) and moist bulk density. In our case, we used Arc-SWAT to compile the SWAT input factors.

$$
\begin{aligned}
& \text { Sed =11.8 (Qsurf } \left.\left.\times \mathrm{q}_{\text {peak }} \times \text { area }_{\text {hru }}\right)^{0.56} \times \mathrm{K}(\text { usle }) \times \mathrm{P}(\text { usle }) \times \mathrm{C}(\text { usle }) \times \mathrm{LS}(\text { usle }) \times \text { CFRG }\right) \\
& \text { where: } \\
& \text { Sed is the sediment yield on a given day (tons), } \\
& \text { Qsurf is the surface runof volume }\left(\mathrm{mm} \mathrm{H}_{2} \mathrm{O} / \mathrm{ha}\right), \\
& \text { qpeak is the peak runof rate }(\mathrm{m} 3 / \mathrm{s}), \\
& \text { Areahru is the area of the HRU (ha), } \\
& \text { KUSLE is the soil erodability factor } \\
& \text { CUSLE is the cover and management factor, } \\
& \text { PUSLE is the support practice factor, } \\
& \text { LSUSLE is the topographic factor and CFRG is the coarse fragment factor }
\end{aligned}
$$

\subsubsection{Spatial Autocorrelation Analysis}

The spatial autocorrelation represents the spatial dependence between numerical values of a spatially located variable. It is used to assesses spatial autocorrelation using both feature locations and feature values at the same time. The most commonly autocorrelation index used is the Global Moran's [66]. It determines whether the pattern displayed is clustered, scattered, or random based on a collection of characteristics and an associated attribute. The Global Moran's I range from -1 to 1 . If the absolute value is more approaching 1, it means it has a stronger autocorrelation [66]. In this study, the Global Moran's I was used to characterize the spatial relationships between soil erosion risks for both RUSLE equation and SWAT model.

\section{Results and Discussion}

\subsection{Stream Flow}

To test the applicability of the SWAT model, we based on the comparison of the monthly hydrograph and simulated flows at the Souk Elhad station. During the calibration for the period of 2002 to 2009, we used the sequential uncertainty fitting version 2 (SUFI-2) algorithm.

Our results showed that the SUFI-2 gives good results with $-1.1 \%$ for the Pbais factor and the high values of $\mathrm{R}^{2}$ and the NSE larger than 0.75 and 0.70 respectively. The sensitivity analysis results of the model to each sub-basin delineation and HRU in this basin are 1613 HRUs in the whole watershed. Regarding the uncertainty results, the 95\% prediction uncertainty (95PPU) was well correlated with the observed flow. Figure 4 shows the comparison of observed and simulated monthly flows for the Souk Elhad station for the calibration period. it is was showed that both the simulated and observed flows are well correlated.

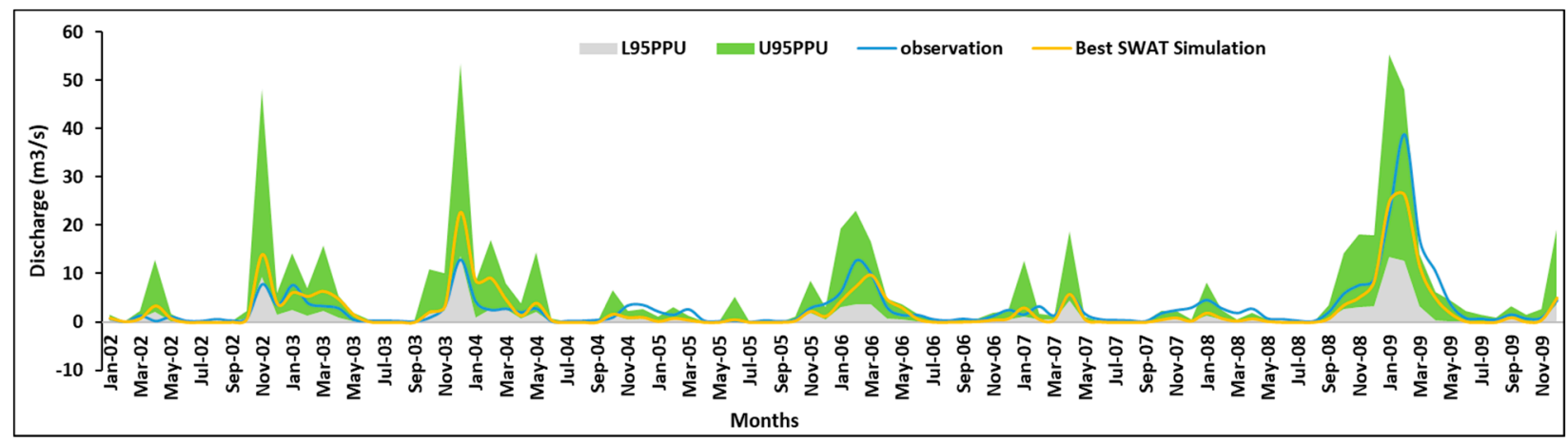

Figure 4. Observed and Simulated Monthly Streamflow for Souk Elhad station. 


\subsection{Factors Maps Analysis}

Figure $5 \mathrm{a}, \mathrm{b}$ shows the spatial distribution of $\mathrm{R}$ factor covering the study area during the two periods 2000-2013 and 2014-2027. The results show that this R-factor ranged from 673 to $1480.6 \mathrm{MJ} \cdot \mathrm{mm} /(\mathrm{ha} \cdot \mathrm{hr} \cdot \mathrm{y})$ for the first period and from 729.2 to $2214.6 \mathrm{MJ} \cdot \mathrm{mm} /(\mathrm{ha} \cdot \mathrm{hr} \cdot \mathrm{y})$ for the second period.
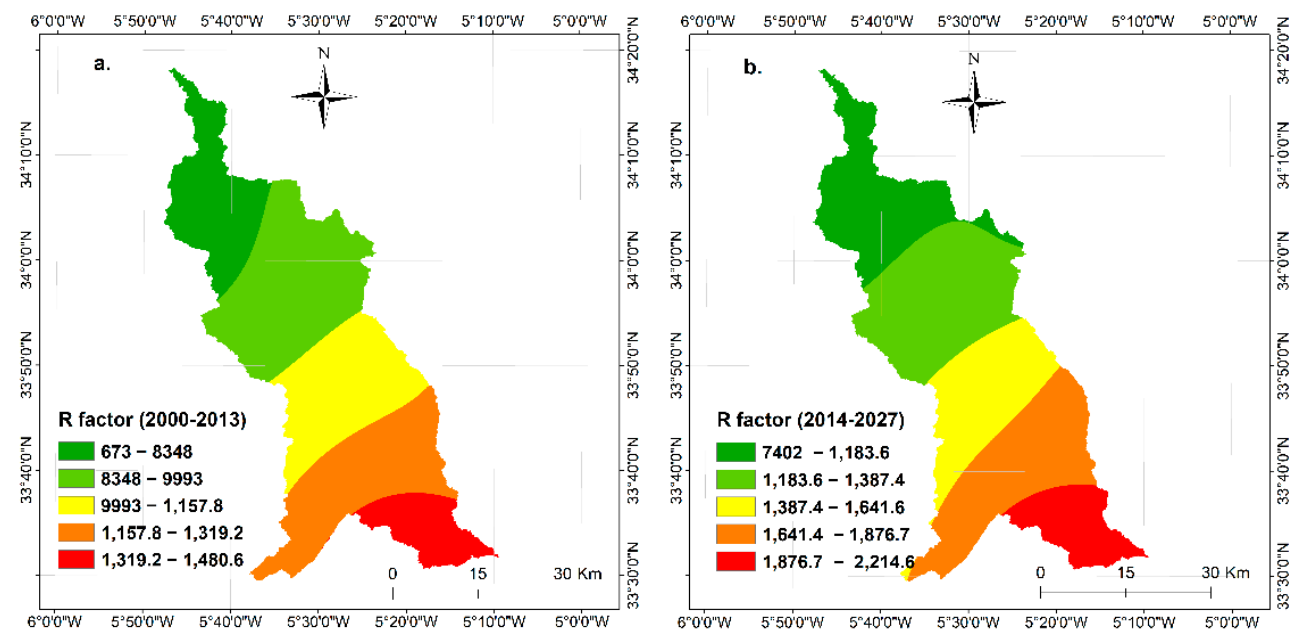

Figure 5. Spatial distribution of erosivity (R) for R'Dom watershed. (a) 2000/2013 and (b) 2014/2027.

The results of LS factor (Figure 6a) show that the watershed is relatively flat with LS values range between 0 and $15 \%$. The most part of the study area has low LS factor values, the relatively high values of the LS factor $(>15 \%)$ are mostly located in the eastern and western and the north parts of the basin. The range of elevation in the study area is from 29 to $1778 \mathrm{~m}$ (Figure 7a).

The spatial distribution of soil erodibility factor is given in the Figure $6 \mathrm{~b}$. The soil erodibility factor was found in the range of 0.003 to 0.0081 . The major soil groups in the watershed are presented in Figure 7d.

The Figure $6 \mathrm{c}$ shows the spatial distribution of $C$ factor with values ranging from 0.016 to 0.138 . C factor values close to 0 indicate well-protected land cover and good conservation efforts, while values close to 1 indicate urbanized area and barren land, as well as agricultural fields that are exposed to heavy rainfall. Therefore, the results of this factor show that the southern and northern parts are most affected. In this study, Land Use/Land Cover (LULC) map produced is shown in Figure 7c.
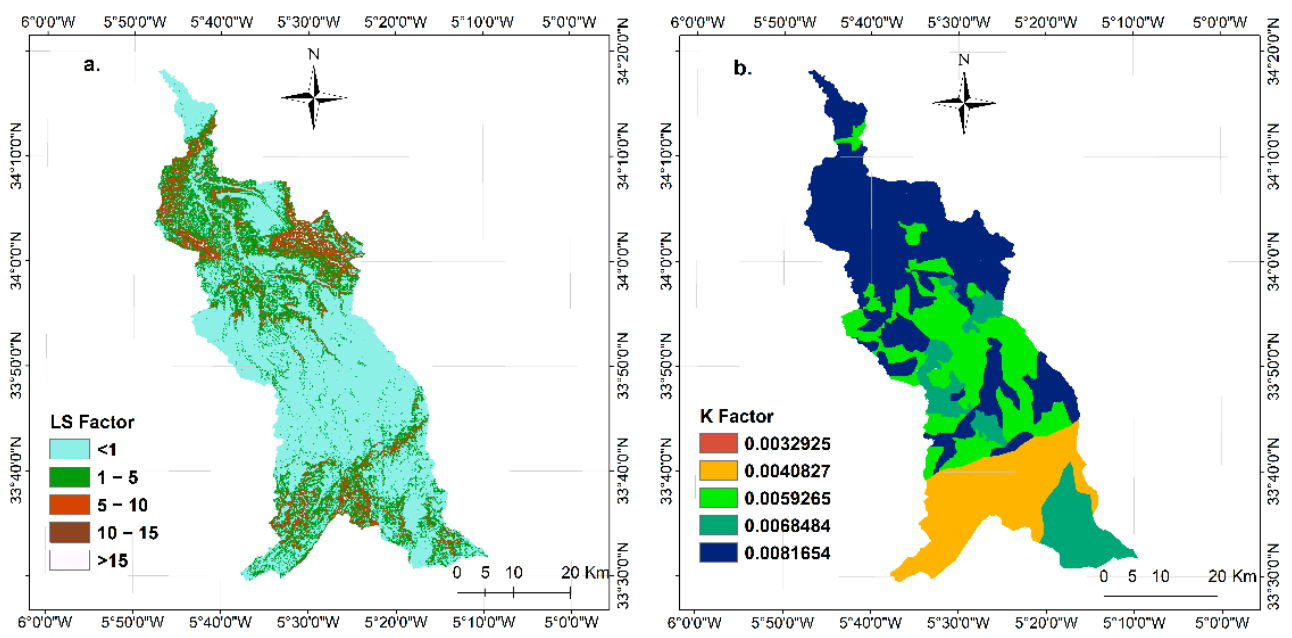

Figure 6. Cont. 

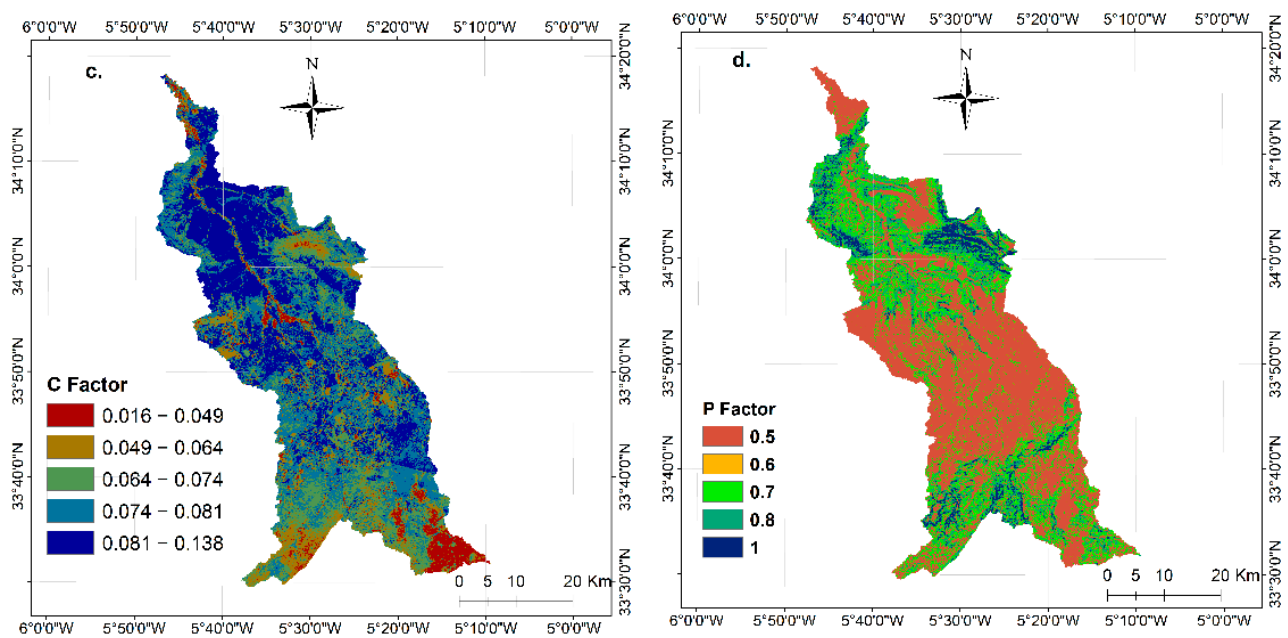

Figure 6. Spatial distribution of USLE parameters: (a) Slope Length (LS-factor); (b) Soil erodibility (K); (c) Crop and management; (d) Support practice factor (P) maps.
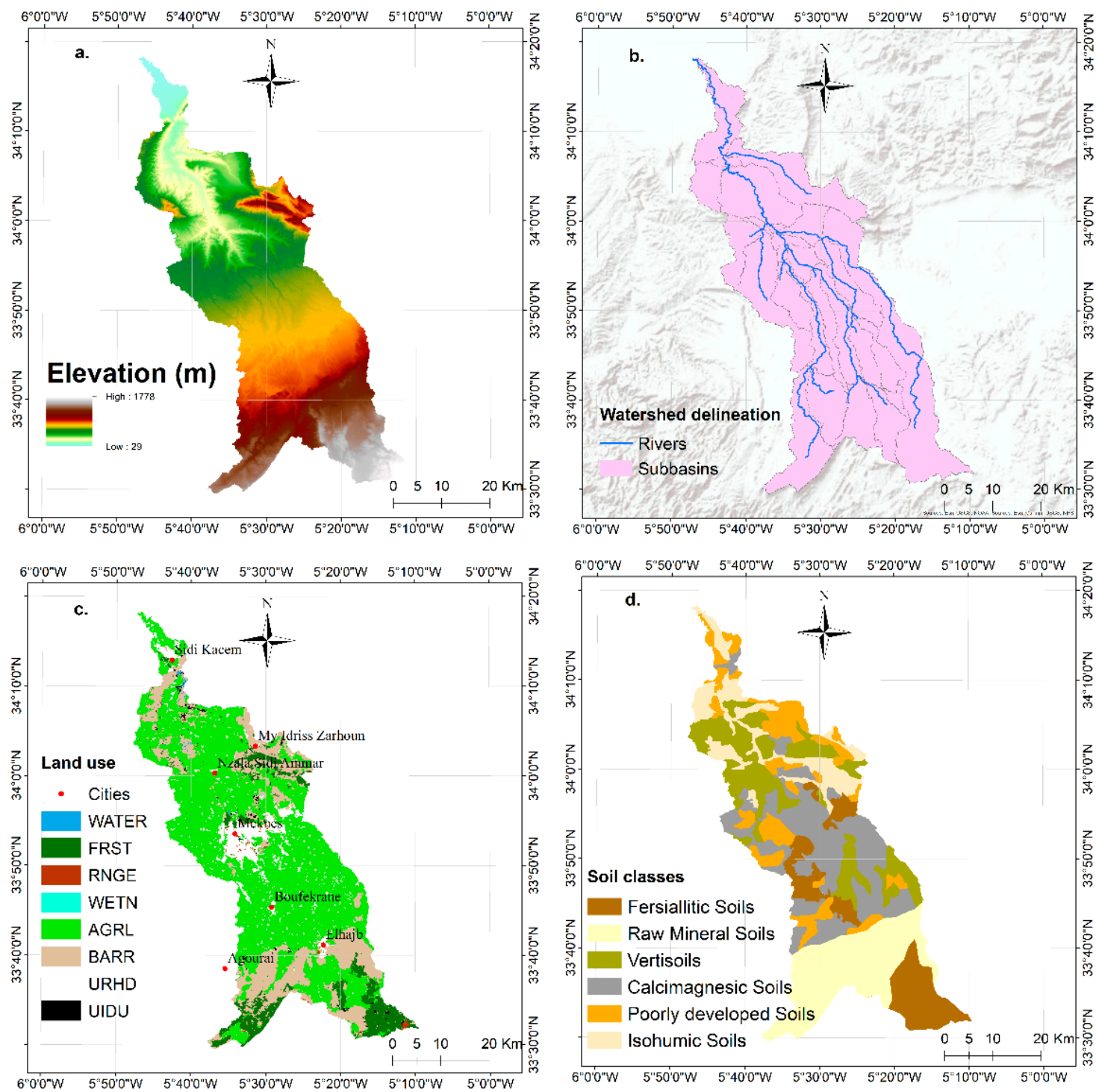

Figure 7. Spatial distribution of SWAT parameters: (a) Elevation (m), (b) Watershed delineation, (c) Land use and (d) Soil classes maps. 
The $\mathrm{P}$ factor (Figure $6 \mathrm{~d}$ ) value ranged from 0.55 to 1 where a higher value indicates there is no any support practice such that erosion is at its maximum due to the absence of any practice.

\subsection{Spatial Distribution of Soil Erosion Rate}

\subsubsection{Soil Erosion Rate Using RUSLE Method}

The spatial distribution maps of soil erosion using RUSLE method during the period 2000/2013 and 2014/2027 are presented in Figure 8. The areas of soil erosion classes are given in Table 6.
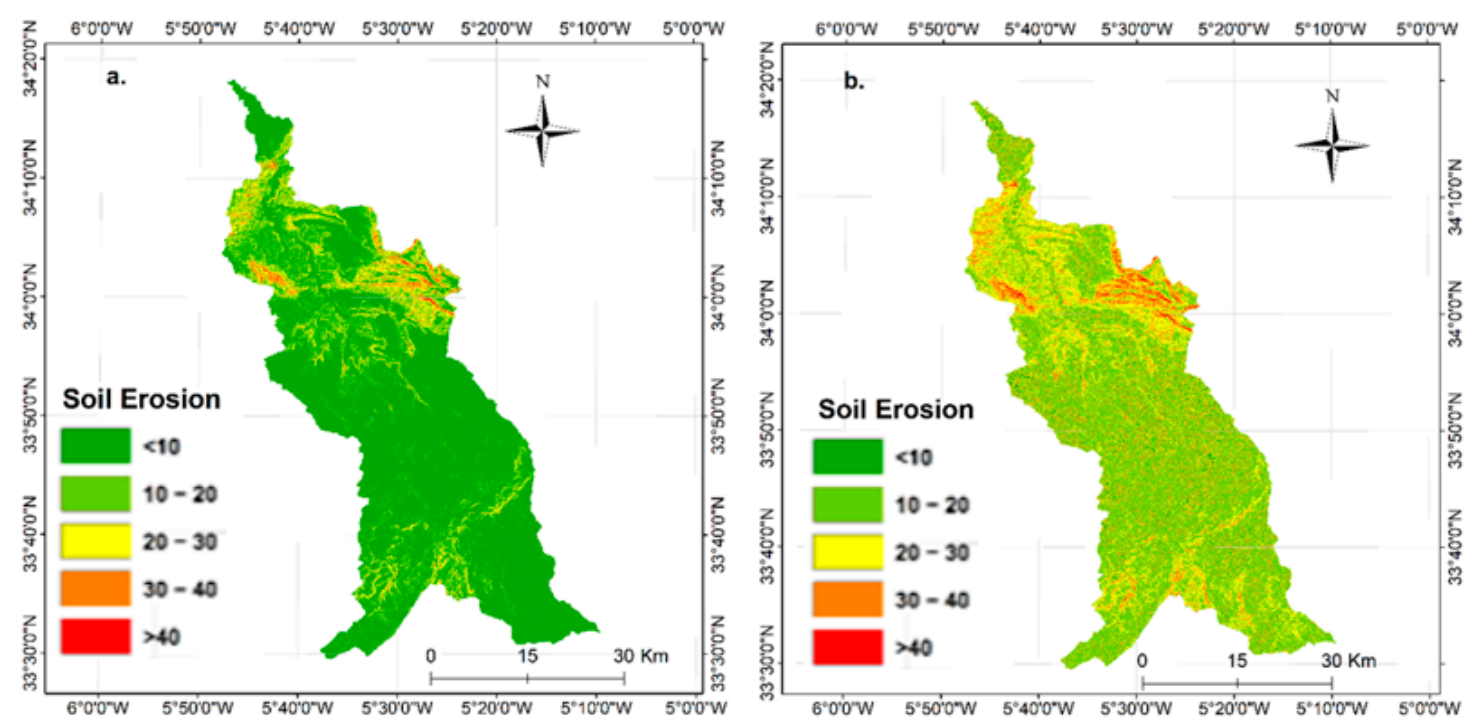

Figure 8. Soil erosion rate for using RUSLE model (a) for the period 2000-2013, (b) for the period 2014-2027.

Table 6. Soil erosion classes with area occupied using RUSLE model.

\begin{tabular}{ccccc}
\hline & \multicolumn{2}{c}{$\mathbf{2 0 0 0 - 2 0 1 3}$} & \multicolumn{2}{c}{ 2014-2027 } \\
\hline Soil Erosion Severity Class & Soil Loss $\left(\mathbf{t ~ h a}^{\mathbf{- 1}}\right)$ & Area (\%) & Soil Loss (t ha $\left.{ }^{-\mathbf{1}}\right)$ & Area (\%) \\
\hline Very low & $<10$ & 71.90 & $<10$ & 58.33 \\
\hline Low & $10-20$ & 20.20 & $10-20$ & 27.71 \\
\hline Moderate & $20-30$ & 6.25 & $20-30$ & 11.94 \\
\hline High & $30-40$ & 1.42 & $30-40$ & 1.73 \\
\hline Very high & $>40$ & 0.20 & $>40$ & 0.27 \\
\hline
\end{tabular}

The results obtained for the $2000 / 2013$ period showed that $71.90 \%$ of the total area of the watershed is exposed to a very low erosion, whereas only $0.20 \%$ of the area was exposed to a very high-risk erosion, and the results obtained for the period of 2014/2027, showed that the study area is expected to have a very low erosion risk for a portion of $58.33 \%$ of the total area, and a very high risk for $0.27 \%$.

It can be seen that the risk of erosion is very low in the basin, especially in the central part, which belongs to the Saiss plain characterized by down slope, and the rate of erosion is relatively high in the areas characterized by heterogeneity of relief, located especially in the north parts of the study area.

\subsubsection{Soil Erosion Rate Using SWAT Model}

The spatial distribution maps of the soil erosion using SWAT model during the period 2000/2013 and 2014/2027 are presented in Figure 9. The areas of soil erosion classes are 
given in Table 7, The results obtained for the period of $2000 / 2013$ showed that $35.57 \%$ of the total area of the watershed is exposed to a very low erosion, whereas only $9 \%$ of the area was exposed to a very high risk erosion, and the results obtained for the period 2014/2027 showed that the study area is expected to have a very low erosion risk for a portion of $36.97 \%$ of the total area, and a very high risk for $9.24 \%$.
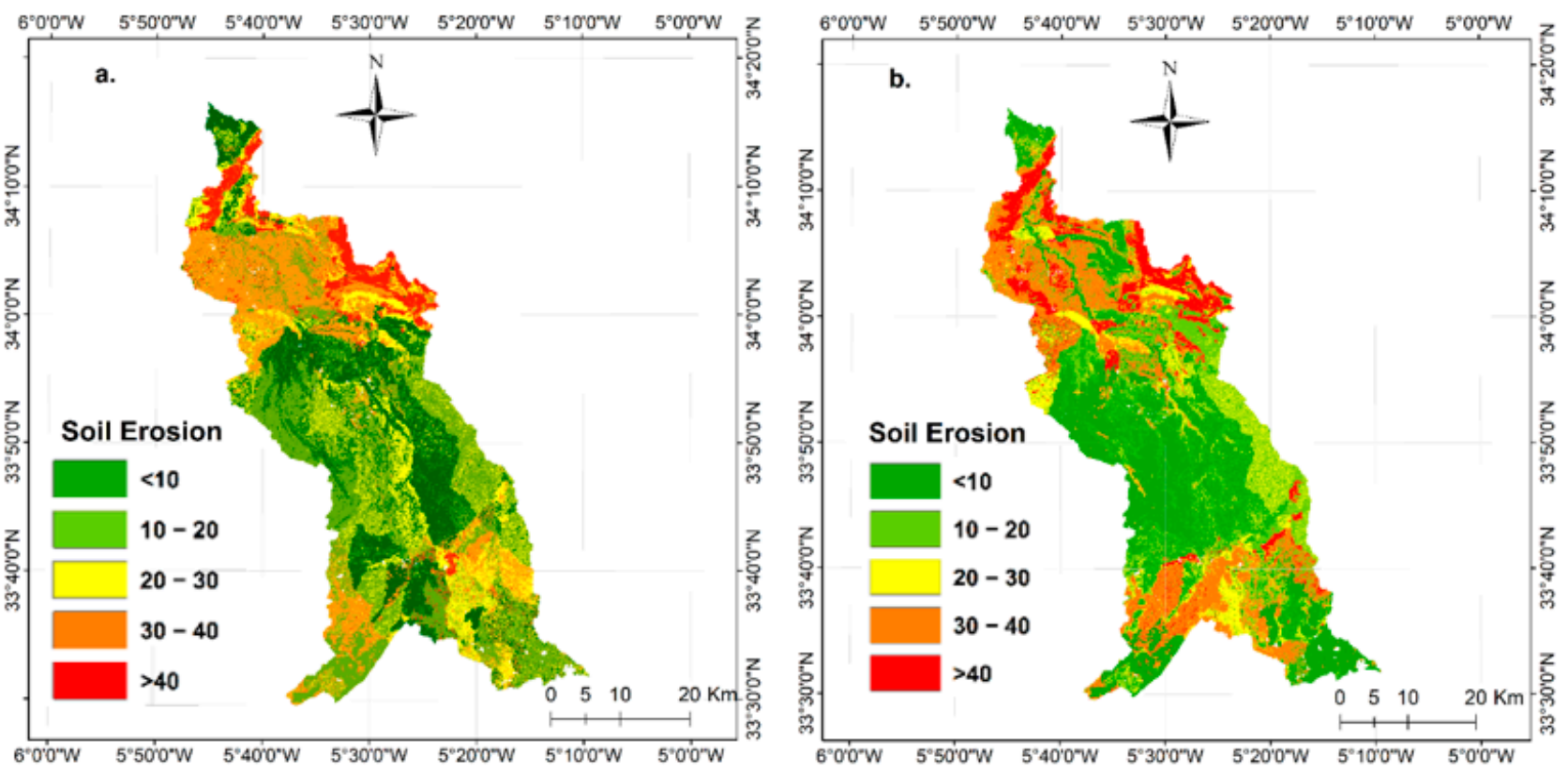

Figure 9. Soil erosion rate for using SWAT model (a) for the period 2000-2013, (b) for the period 2014-2027.

Table 7. Soil erosion classes with area occupied using SWAT model.

\begin{tabular}{|c|c|c|c|c|}
\hline \multirow[b]{2}{*}{ Soil Erosion Severity Class } & \multicolumn{2}{|c|}{ 2000-2013 } & \multicolumn{2}{|c|}{ 2014-2027 } \\
\hline & Soil Loss (t ha $\left.{ }^{-1}\right)$ & Area $(\%)$ & Soil Loss (t ha-1) & Area $(\%)$ \\
\hline Very low & $<10$ & 35.57 & $0-10$ & 36.97 \\
\hline Low & $10-20$ & 28.28 & $10-20$ & 25.22 \\
\hline Moderate & $20-30$ & 18.45 & $20-30$ & 18.35 \\
\hline High & $30-40$ & 8.7 & $30-40$ & 10.21 \\
\hline Very high & $>40$ & 9.00 & $>40$ & 9.24 \\
\hline
\end{tabular}

It is important to highlighted here that the affected areas by soil erosion are expected to be affected in the future in the north and south parts of the watershed. This is strongly linked to the morphology of the watershed and the slope factor. The lowest total soil erosion is observed in the center parts of the watershed, characterized by down slopes.

\subsection{Soil Erosion Rate in Relation to Land Use}

Using the 'Zonal Statistics' toolset and cross-tabulate (available in ArcGIS 10.4), the relation between soil erosion rate and LULC for both RUSLE and SWAT was established. From the examination of Tables 8 and 9, it was verified that erosion loss was found mainly in agricultural lands (AGRL) with an area of $48.1 \%$ and $59.58 \%$, Followed by bare lands (BARR) with $38.27 \%$ and $25.26 \%$ in RUSLE equation and SWAT model respectively. These findings are in line with the results of previous studies [67]. 
Table 8. Soil erosion rate in relation to land use using RUSLE equation.

\begin{tabular}{ccccccc}
\hline & Area (\%) & Very Low & Low & Moderate & High & Very High \\
\hline Water & 0.15 & 0.09 & 0.36 & 0.17 & 0.10 & 0.00 \\
\hline forest & 8.01 & 7.66 & 5.53 & 8.58 & 10.74 & 7.53 \\
\hline Range-Grasses & 0.1 & 0.19 & 0.14 & 0.13 & 0.06 & 0.00 \\
\hline Wetlands-Non-Forested & 0.00 & 0.00 & 0.00 & 0.00 & 0.00 & 0.00 \\
\hline Agricultural Land-Generic & 48.1 & 67.45 & 61.06 & 48.45 & 35.89 & 27.65 \\
\hline Barren & 38.27 & 15.25 & 26.19 & 38.01 & 50.12 & 61.80 \\
\hline Residential-High Density & 4.83 & 8.83 & 5.90 & 3.85 & 2.55 & 3.01 \\
\hline Industrial & 0.51 & 0.48 & 0.79 & 0.78 & 0.51 & 0.00 \\
\hline
\end{tabular}

Table 9. Soil erosion rate in relation to land use using SWAT model.

\begin{tabular}{cccccccc}
\hline & Area (\%) & Very Low & Low & Moderate & Very High & High \\
\hline Water & 0.12 & 0.05 & 0.01 & 0.41 & 0.05 & 0.09 \\
\hline Forest & 7.33 & 4.67 & 14.95 & 3.93 & 5.82 & 7.30 \\
\hline Range-Grasses & 0.06 & 0.11 & 0.04 & 0.15 & 0.01 & 0.01 \\
\hline Wetlands-Non-Forested & 0.00 & 0.00 & 0.00 & 0.00 & 0.00 & 0.00 \\
\hline Agricultural Land-Generic & 59.58 & 75.47 & 68.26 & 66.08 & 56.03 & 32.05 \\
\hline Barren & 25.26 & 11.01 & 8.43 & 19.18 & 34.35 & 53.32 \\
\hline Residential-High Density & 7.30 & 8.39 & 8.01 & 10.09 & 2.90 & 7.03 \\
\hline Industrial & 0.33 & 0.27 & 0.27 & 0.12 & 0.82 & 0.17 \\
\hline
\end{tabular}

\subsection{Spatial Autocorrelation of Soil Erosion Rate}

The spatial autocorrelation analysis report for both RUSLE and SWAT methods were obtained using the spatial autocorrelation analysis tool in the ArcGIS 10.4 toolbox. In addition to the global Moran's index, the analysis results in the report also include z-scores and p-values, to determine the index's significance. P-values are numerical estimates of the area under the curve given a known distribution, using the test statistic as a constraint. The results of the Moran's I index are shown in Table 10 and Figure 10. According to the results, the value of Moran's I index for the RUSEL equation and SWAT model was 0.12 and 0.32 , respectively. According to these results both the models present a positive correlation at a spatial distribution. $p$-value is 0.000 (it is lower than 0.01 ), which indicates that the random distribution probability is less than $1 \%$. Furthermore, z-score is higher than 2.58 , which demonstrates that the spatial aggregation trend of the erosion loss at global distribution is significant.

Table 10. Result of Moran's I index.

\begin{tabular}{ccc}
\hline Moran's I & RUSLE Equation & SWAT Model \\
\hline Moran's Index & 0.12 & 0.32 \\
\hline Variance & 0.00 & 0.00 \\
\hline z-score & 125.37 & 731.57 \\
\hline$p$-value & 0 & 0 \\
\hline
\end{tabular}




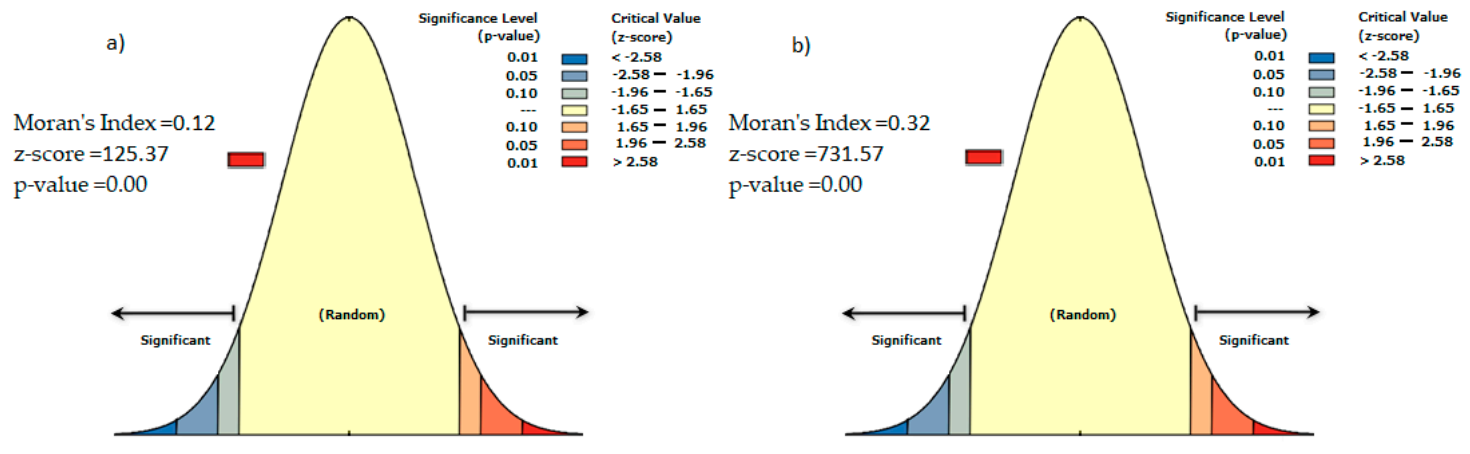

Figure 10. Result of Moran's I index for (a) the Rusle equation and (b) the SWAT model.

The phenomenon of erosion is a serious problem that requires intervention, especially in agricultural areas, and its management is necessary for sustainable land use and overall soil conservation management. RS techniques and GIS tools are integrative and generative tools for prevention, warning, monitoring and modelling of environmental hazards. In the current study, the methodology applied showed a strong capacity in estimating soil losses in the R'Dom watershed. Our results are quantitatively and spatially quite similar between the two methods. As we found out, high risk erosion is mainly concentrated in the agricultural land and barren lands, where erosion is very high. These results are in line with previously published studies $[68,69]$.Thus, further policy interventions are therefore very urgent.

In summary, the results of our study showed that the study area is not largely affected by soil erosion. These is also confirmed by other authors in other areas with similar background in Morocco, for example the results of a study conducted by [70] showed that the rate of soil loss was $7-20 \mathrm{t} \mathrm{ha}^{-1}$, accounting for $75 \%$ of the basin area. Likewise, the rate of soil loss was estimated at $3.95 \mathrm{t} \mathrm{ha}^{-1}$ at the $\mathrm{M}^{\prime}$ dez Watershed when calculated by the RUSLE model, and the results of SWAT method showed that the soil loss is estimated at $2.94 \mathrm{t} \mathrm{ha}^{-1}$ according to Boufala et al. [38]. Conversely, Tahiri et al. [71] indicated that the soil loss reached $47.18 \%$ in the Oued Haricha Sub-Basin, Western Rif. Thus, in terms of the efficacity of the used approaches and the outcomes obtained, both these methodologies could be useful in other areas where the soil erosion is a heavy issue.

\section{Conclusions}

This study proposes an approach to estimate the mean annual soil erosion in the R' Dom watershed Morocco. In this way, for the first time, the RUSLE equation and SWAT model were used based on the use of GIS and remote sensing through the exploitations of open source and free of charge data. The main results of our study are listed below.

- $\quad$ Standard calibration statistics were used to assess the performance of SWAT model. Comparison of modeled and observed monthly streamflow datasets resulted from R2, NSE, and PBIAS values of $0.75,0.70$, and -1.1 respectively, which indicated that the hydrological cycle of the R'Dom watershed could be accurately simulated using the SWAT model.

- $\quad$ The erosion rate values vary from 0 to $8 \mathrm{t} \mathrm{ha}^{-1}$ for both periods. For the 2000/2013 period, the RUSLE showed that $71.90 \%$ of the total area of the watershed is exposed to a very low erosion, whereas only $0.02 \%$ of the area was exposed to a very high erosion, while the SWAT showed that $35.57 \%$ is exposed to a very low erosion, whereas only $9 \%$ of the area was exposed to a very high erosion. For the period of $2014 / 2027$ it is expected to have a very low erosion risk for a portion of $58.33 \%$ and $36.97 \%$ of the total area, and a very high risk for $0.27 \%$ and $9.24 \%$ for RUSLE method and SWAT respectively. 
- It was verified that erosion loss was found mainly in agricultural lands (AGRL) with an area of $48.1 \%$ and $59.58 \%$, Followed by bare lands (BARR) with $38.27 \%$ and $25.26 \%$ in RUSLE equation and SWAT model respectively.

This study demonstrates that GIS provides a flexible environment for spatial analysis and data manipulation due to its ability to process large amounts of spatial data necessary for erosion studies, also RS imagery is the most important data resources of GIS, providing a spectrum of imaging capabilities, resolutions, temporal and spatial coverage. RS plays a pivotal role in achieving these objectives. Furthermore, the results obtained from this study can provide a valuable assistance, at very low cost, to decision-makers in simulating evolution scenarios and then targeting priority areas that require conservation and erosion control actions. Finally, the validation of the estimated soil erosion rates of this study area can be further done with field sampling data, which are the main gap of this work.

Author Contributions: Conceptualization, A.A., A.E. and A.v.G.; Data curation, A.A., A.E., M.E.H. and Y.E.Y.; Formal analysis, A.A. and A.E.; Funding acquisition, A.E., A.v.G., C.J.C. and A.V.R.; Investigation, A.A. and A.E.; Methodology, A.A., A.E.; Project administration, A.E.; Resources, A.A., A.E., A.v.G., C.J.C., A.V.R., A.E.H., A.E.O. and A.K.; Software, A.A., A.E., M.E.H. and Y.E.Y.; Supervision, A.E., A.v.G. and A.V.R.; Validation, A.A. and A.E.; Visualization, A.A., A.E. and M.E.H.; Writing—original draft, A.A.; Writing—review \& editing, A.A., A.E. and A.K. All authors have read and agreed to the published version of the manuscript.

Funding: This research received no external funding.

Institutional Review Board Statement: Not applicable.

Informed Consent Statement: Not applicable.

Acknowledgments: The authors would like to thank the Thematic Project 4, Integrated Water Resources Management of the institutional university cooperation, and VLIR-UOS for the financial support, equipment and mission in Belgium. Special thanks go to Meriame Mohajane for her assistance with English proofreading and reviewing the manuscript.

Conflicts of Interest: The authors declare no conflict of interest.

\section{References}

1. Saavedra, C. Estimating Spatial Patterns of Soil Erosion and Deposition in the Andean Region Using Geo-Information Techniques: A Case Study in Cochabamba, Bolivia; ITC Dissertation: Wageningen, the Netherlands, 2005; ISBN 978-90-8504-289-1.

2. Chuenchum, P.; Xu, M.; Tang, W. Estimation of Soil Erosion and Sediment Yield in the Lancang-Mekong River Using the Modified Revised Universal Soil Loss Equation and GIS Techniques. Water 2019, 12, 135. [CrossRef]

3. Anees, M.T.; Abdullah, K.; Nawawi, M.N.M.; Norulaini, N.A.N.; Syakir, M.I.; Omar, A.K.M. Soil Erosion Analysis by RUSLE and Sediment Yield Models Using Remote Sensing and GIS in Kelantan State, Peninsular Malaysia. Soil Res. 2018, 56, 356. [CrossRef]

4. Zhang, Y.; Degroote, J.; Wolter, C.; Sugumaran, R. Integration of Modified Universal Soil Loss Equation (MUSLE) into a Gis Framework to Assess Soil Erosion Risk: Gis Musle Model to Assess Soil Erosion Risk. Land Degrad. Dev. 2009, $20,84-91$. [CrossRef]

5. Kopittke, P.M.; Menzies, N.W.; Wang, P.; McKenna, B.A.; Lombi, E. Soil and the Intensification of Agriculture for Global Food Security. Environ. Int. 2019, 132, 105078. [CrossRef]

6. Sartori, M.; Philippidis, G.; Ferrari, E.; Borrelli, P.; Lugato, E.; Montanarella, L.; Panagos, P. A Linkage between the Biophysical and the Economic: Assessing the Global Market Impacts of Soil Erosion. Land Use Policy 2019, 86, 299-312. [CrossRef]

7. UN (United Nations). Draft Resolution Submitted by the Vice-Chair of the Committee, Ms. Farrah Brown (Jamaica), on the Basis of Informal Consultations on Draft Resolution A/C.2/68/L.21; United Nations General Assembly: Washington, DC, USA, 2013.

8. Tóth, G.; Hermann, T.; da Silva, M.R.; Montanarella, L. Monitoring Soil for Sustainable Development and Land Degradation Neutrality. Environ. Monit. Assess. 2018, 190, 57. [CrossRef]

9. Cramer, W.; Guiot, J.; Fader, M.; Garrabou, J.; Gattuso, J.-P.; Iglesias, A.; Lange, M.A.; Lionello, P.; Llasat, M.C.; Paz, S.; et al. Climate Change and Interconnected Risks to Sustainable Development in the Mediterranean. Nat. Clim. Chang. 2018, 8, 972-980. [CrossRef]

10. Knippertz, P.; Christoph, M.; Speth, P. Long-Term Precipitation Variability in Morocco and the Link to the Large-Scale Circulation in Recent and Future Climates. Meteorol. Atmos. Phys. 2003, 83, 67-88. [CrossRef]

11. García Martinez, M.; Poole, N. The Development of Private Fresh Produce Safety Standards: Implications for Developing Mediterranean Exporting Countries. Food Policy 2004, 29, 229-255. [CrossRef] 
12. Abdelwahab, O.M.M.; Ricci, G.F.; De Girolamo, A.M.; Gentile, F. Modelling Soil Erosion in a Mediterranean Watershed: Comparison between SWAT and AnnAGNPS Models. Environ. Res. 2018, 166, 363-376. [CrossRef]

13. Shen, Z.Y.; Gong, Y.W.; Li, Y.H.; Hong, Q.; Xu, L.; Liu, R.M. A Comparison of WEPP and SWAT for Modeling Soil Erosion of the Zhangjiachong Watershed in the Three Gorges Reservoir Area. Agric. Water Manag. 2009, 96, 1435-1442. [CrossRef]

14. Pham, T.G.; Degener, J.; Kappas, M. Integrated Universal Soil Loss Equation (USLE) and Geographical Information System (GIS) for Soil Erosion Estimation in A Sap Basin: Central Vietnam. Int. Soil Water Conserv. Res. 2018, 6, 99-110. [CrossRef]

15. Park, S.; Oh, C.; Jeon, S.; Jung, H.; Choi, C. Soil Erosion Risk in Korean Watersheds, Assessed Using the Revised Universal Soil Loss Equation. J. Hydrol. 2011, 399, 263-273. [CrossRef]

16. Fortuño Ibáñez, J.; Gómez Valentín, M.; Jang, D. Application of the KINEROS 2 Model to Natural Basin for Estimation of Erosion. Appl. Sci. 2021, 11, 9320. [CrossRef]

17. Berteni, F.; Grossi, G. Water Soil Erosion Evaluation in a Small Alpine Catchment Located in Northern Italy: Potential Effects of Climate Change. Geosciences 2020, 10, 386. [CrossRef]

18. Thomas, K.; Chen, W.; Lin, B.-S.; Seeboonruang, U. Evaluation of the SEdiment Delivery Distributed (SEDD) Model in the Shihmen Reservoir Watershed. Sustainability 2020, 12, 6221. [CrossRef]

19. Ouyang, W.; Hao, F.; Skidmore, A.K.; Toxopeus, A.G. Soil Erosion and Sediment Yield and Their Relationships with Vegetation Cover in Upper Stream of the Yellow River. Sci. Total Environ. 2010, 409, 396-403. [CrossRef]

20. Baigorria, G.A.; Romero, C.C. Assessment of Erosion Hotspots in a Watershed: Integrating the WEPP Model and GIS in a Case Study in the Peruvian Andes. Environ. Model. Softw. 2007, 22, 1175-1183. [CrossRef]

21. Haregeweyn, N.; Yohannes, F. Testing and Evaluation of the Agricultural Non-Point Source Pollution Model (AGNPS) on Augucho Catchment, Western Hararghe, Ethiopia. Agric. Ecosyst. Environ. 2003, 99, 201-212. [CrossRef]

22. Beasley, D.B.; Huggins, L.F.; Monke, E.J. ANSWERS: A Model for Watershed Planning. Trans. ASAE 1980, $23,0938-0944$. [CrossRef]

23. Grum, B.; Woldearegay, K.; Hessel, R.; Baartman, J.E.M.; Abdulkadir, M.; Yazew, E.; Kessler, A.; Ritsema, C.J.; Geissen, V. Assessing the Effect of Water Harvesting Techniques on Event-Based Hydrological Responses and Sediment Yield at a Catchment Scale in Northern Ethiopia Using the Limburg Soil Erosion Model (LISEM). Catena 2017, 159, 20-34. [CrossRef]

24. Veihe, A.; Rey, J.; Quinton, J.N.; Strauss, P.; Sancho, F.M.; Somarriba, M. Modelling of Event-Based Soil Erosion in Costa Rica, Nicaragua and Mexico: Evaluation of the EUROSEM Model. Catena 2001, 44, 187-203. [CrossRef]

25. de Jong, S.M.; Paracchini, M.L.; Bertolo, F.; Folving, S.; Megier, J.; de Roo, A.P.J. Regional Assessment of Soil Erosion Using the Distributed Model SEMMED and Remotely Sensed Data. Catena 1999, 37, 291-308. [CrossRef]

26. Williams, J.R.; Nicks, A.D.; Arnold, J.G. Simulator for Water Resources in Rural Basins. J. Hydraul. Eng. 1985, 111, 970-986. [CrossRef]

27. Morgan, R.P.C. A Simple Approach to Soil Loss Prediction: A Revised Morgan-Morgan-Finney Model. Catena 2001, 44, 305-322. [CrossRef]

28. Wang, H.; Wu, Z.; Hu, C. A Comprehensive Study of the Effect of Input Data on Hydrology and Non-Point Source Pollution Modeling. Water Resour. Manag. 2015, 29, 1505-1521. [CrossRef]

29. Hajigholizadeh, M.; Melesse, A.; Fuentes, H. Erosion and Sediment Transport Modelling in Shallow Waters: A Review on Approaches, Models and Applications. Int. J. Environ. Res. Public Health 2018, 15, 518. [CrossRef]

30. Brzezińska, M.; Szatten, D.; Babiński, Z. Prediction of Erosion-Prone Areas in the Catchments of Big Lowland Rivers: Implementation of Maximum Entropy Modelling-Using the Example of the Lower Vistula River (Poland). Remote Sens. 2021, 13, 4775. [CrossRef]

31. Arabameri, A.; Tiefenbacher, J.P.; Blaschke, T.; Pradhan, B.; Tien Bui, D. Morphometric Analysis for Soil Erosion Susceptibility Mapping Using Novel GIS-Based Ensemble Model. Remote Sens. 2020, 12, 874. [CrossRef]

32. Zaimes, G.N.; Schultz, R.C. Assessing Riparian Conservation Land Management Practice Impacts on Gully Erosion in Iowa Environ. Manag. 2012, 49, 1009-1021. [CrossRef] [PubMed]

33. Rahmati, O.; Haghizadeh, A.; Pourghasemi, H.R.; Noormohamadi, F. Gully Erosion Susceptibility Mapping: The Role of GIS-Based Bivariate Statistical Models and Their Comparison. Nat. Hazards 2016, 82, 1231-1258. [CrossRef]

34. Conoscenti, C.; Angileri, S.; Cappadonia, C.; Rotigliano, E.; Agnesi, V.; Märker, M. Gully Erosion Susceptibility Assessment by Means of GIS-Based Logistic Regression: A Case of Sicily (Italy). Geomorphology 2014, 204, 399-411. [CrossRef]

35. Gómez-Gutiérrez, Á.; Conoscenti, C.; Angileri, S.E.; Rotigliano, E.; Schnabel, S. Using Topographical Attributes to Evaluate Gully Erosion Proneness (Susceptibility) in Two Mediterranean Basins: Advantages and Limitations. Nat. Hazards 2015, 79, 291-314 [CrossRef]

36. Rafiei, V.; Ghahramani, A.; An-Vo, D.-A.; Mushtaq, S. Modelling Hydrological Processes and Identifying Soil Erosion Sources in a Tropical Catchment of the Great Barrier Reef Using SWAT. Water 2020, 12, 2179. [CrossRef]

37. Boufala, M.; El Hmaidi, A.; Chadli, K.; Essahlaoui, A.; El Ouali, A.; Taia, S. Hydrological Modeling of Water and Soil Resources in the Basin Upstream of the Allal El Fassi Dam (Upper Sebou Watershed, Morocco). Model. Earth Syst. Environ. $2019,5,1163-1177$. [CrossRef]

38. Boufala, M.; El Hmaidf, A.; Chadli, K.; Essahlaoui, A.; El Ouali, A.; Lahjouj, A. Assessment of the Risk of Soil Erosion Using RUSLE Method and SWAT Model at the M'dez Watershed, Middle Atlas, Morocco. E3S Web Conf. 2020, 150, 03014. [CrossRef] 
39. Chadli, K. Estimation of Soil Loss Using RUSLE Model for Sebou Watershed (Morocco). Model. Earth Syst. Environ. $2016,2,51$. [CrossRef]

40. Williams, J.R.; Agricultural Research Service, U.S. Present and Prospective Technology for Predicting Sediment Yield and Sources; Agricultural Research Service, U.S. Department of Agriculture: Honolulu, HI, USA, 1975.

41. Chawanda, C.J.; Arnold, J.; Thiery, W.; van Griensven, A. Mass Balance Calibration and Reservoir Representations for Large-Scale Hydrological Impact Studies Using SWAT+. Clim. Chang. 2020, 163, 1307-1327. [CrossRef]

42. Mohajane, M.; Costache, R.; Karimi, F.; Bao Pham, Q.; Essahlaoui, A.; Nguyen, H.; Laneve, G.; Oudija, F. Application of Remote Sensing and Machine Learning Algorithms for Forest Fire Mapping in a Mediterranean Area. Ecol. Indic. 2021, $129,107869$. [CrossRef]

43. Duarte, L.; Teodoro, A.C.; Gonçalves, J.A.; Soares, D.; Cunha, M. Assessing Soil Erosion Risk Using RUSLE through a GIS Open Source Desktop and Web Application. Environ. Monit. Assess. 2016, 188, 351. [CrossRef] [PubMed]

44. Zepner, L.; Karrasch, P.; Wiemann, F.; Bernard, L. ClimateCharts.Net-An Interactive Climate Analysis Web Platform. Int. J. Digit. Earth 2021, 14, 338-356. [CrossRef]

45. Essahlaoui, A.; Ouali, E.A. Détermination de la structure géologique de la partie Sud de la plaine du Saïss (bassin de Meknès-Fès, Maroc) par la méthode géoélectrique. Bull. Eng. Geol. Environ. 2003, 62, 155-166. [CrossRef]

46. Brouziyne, Y.; Abouabdillah, A.; Bouabid, R.; Benaabidate, L.; Oueslati, O. SWAT Manual Calibration and Parameters Sensitivity Analysis in a Semi-Arid Watershed in North-Western Morocco. Arab. J. Geosci. 2017, 10, 427. [CrossRef]

47. Copernicus Open Access Hub. Available online: https://scihub.copernicus.eu/dhus/\#/home (accessed on 13 November 2021).

48. Congedo, L. Semi-Automatic Classification Plugin Documentation. Release 2016, 4, 29. [CrossRef]

49. Chavez, P.S. An Improved Dark-Object Subtraction Technique for Atmospheric Scattering Correction of Multispectral Data. Remote Sens. Environ. 1988, 24, 459-479. [CrossRef]

50. Mohajane, M.; Essahlaoui, A.; Oudija, F.; El Hafyani, M.; Cláudia Teodoro, A. Mapping Forest Species in the Central Middle Atlas of Morocco (Azrou Forest) through Remote Sensing Techniques. ISPRS Int. J. Geo-Inf. 2017, 6, 275. [CrossRef]

51. EarthExplorer. Available online: https:/ / earthexplorer.usgs.gov / (accessed on 13 November 2021).

52. Chakilu, G.G.; Sándor, S.; Zoltán, T. Change in Stream Flow of Gumara Watershed, Upper Blue Nile Basin, Ethiopia under Representative Concentration Pathway Climate Change Scenarios. Water 2020, 12, 3046. [CrossRef]

53. Chen, Y.; Nakatsugawa, M.; Ohashi, H. Research of Impacts of the 2018 Hokkaido Eastern Iburi Earthquake on Sediment Transport in the Atsuma River Basin Using the SWAT Model. Water 2021, 13, 356. [CrossRef]

54. Zhang, H.; Yang, Q.; Li, R.; Liu, Q.; Moore, D.; He, P.; Ritsema, C.J.; Geissen, V. Extension of a GIS Procedure for Calculating the RUSLE Equation LS Factor. Comput. Geosci. 2013, 52, 177-188. [CrossRef]

55. Tessema, Y.M.; Jasińska, J.; Yadeta, L.T.; Świtoniak, M.; Puchałka, R.; Gebregeorgis, E.G. Soil Loss Estimation for Conservation Planning in the Welmel Watershed of the Genale Dawa Basin, Ethiopia. Agronomy 2020, 10, 777. [CrossRef]

56. Wischmeier, W.H.; Smith, D.D. Predicting Rainfall Erosion Losses: A Guide to Conservation Planning; Department of Agriculture, Science and Education Administration: Corvallis, OR, USA, 1978.

57. Beguería, S.; Serrano-Notivoli, R.; Tomas-Burguera, M. Computation of Rainfall Erosivity from Daily Precipitation Amounts. Sci. Total Environ. 2018, 637-638, 359-373. [CrossRef]

58. Petroselli, A.; Apollonio, C.; De Luca, D.L.; Salvaneschi, P.; Pecci, M.; Marras, T.; Schirone, B. Comparative Evaluation of the Rainfall Erosivity in the Rieti Province, Central Italy, Using Empirical Formulas and a Stochastic Rainfall Generator. Hydrology 2021, 8, 171. [CrossRef]

59. Gourfi, A.; Daoudi, L.; Shi, Z. The Assessment of Soil Erosion Risk, Sediment Yield and Their Controlling Factors on a Large Scale: Example of Morocco. J. Afr. Earth Sci. 2018, 147, 281-299. [CrossRef]

60. CPCS (Commission de Pédologie et de Cartographie des Sols). Classification Des Sols. Grognon, France: Laboratoire de Géologie et de Pédologie Ecole Nationale Supérieure d'Agronomie. Available online: https:/ /scholar.google.com/scholar_lookup?title= Classification \%20des\%20sols.\%20Grognon\%2C\%20France \%20\%3A\%20Laboratoire $\% 20$ de $\% 20$ G $\%$ C3\%A9ologie $\% 20$ et $\% 20$ de $\%$ 20P\%C3\%A9dologie\&publication_year=1967\&author=CPCS $\% 20($ Commission $\% 20 \mathrm{de} \% 20 \mathrm{P} \%$ C3\%A9dologie $\% 20 \mathrm{et} \% 20 \mathrm{de} \% 20$ Cartographie\%20des\%20Sols) (accessed on 9 December 2021).

61. De Jong, S.M. Derivation of Vegetative Variables from a Landsat Tm Image for Modelling Soil Erosion. Earth Surf. Process. Landf. 1994, 19, 165-178. [CrossRef]

62. Das, S.; Deb, P.; Bora, P.K.; Katre, P. Comparison of RUSLE and MMF Soil Loss Models and Evaluation of Catchment Scale Best Management Practices for a Mountainous Watershed in India. Sustainability 2020, 13, 232. [CrossRef]

63. Tucker, C.J. Red and Photographic Infrared Linear Combinations for Monitoring Vegetation. Remote Sens. Environ. 1979, 8 , 127-150. [CrossRef]

64. Aga, A.; Chane, B.; Melesse, A. Soil Erosion Modelling and Risk Assessment in Data Scarce Rift Valley Lake Regions, Ethiopia. Water 2018, 10, 1684. [CrossRef]

65. Mahara, G.; Wang, C.; Yang, K.; Chen, S.; Guo, J.; Gao, Q.; Wang, W.; Wang, Q.; Guo, X. The Association between Environmental Factors and Scarlet Fever Incidence in Beijing Region: Using GIS and Spatial Regression Models. Int. J. Environ. Res. Public. Health 2016, 13, 1083. [CrossRef] 
66. Luo, L.; Jiang, J.; Zhang, G.; Wang, L.; Wang, Z.; Yang, J.; Yu, C. Stroke Mortality Attributable to Ambient Particulate Matter Pollution from 1990 to 2015 in China: An Age-Period-Cohort and Spatial Autocorrelation Analysis. Int. J. Environ. Res. Public Health 2017, 14, 772. [CrossRef]

67. Meliho, M.; Khattabi, A.; Mhammdi, N. Spatial Assessment of Soil Erosion Risk by Integrating Remote Sensing and GIS Techniques: A Case of Tensift Watershed in Morocco. Environ. Earth Sci. 2020, 79, 207. [CrossRef]

68. Wang, R.; Zhang, S.; Yang, J.; Pu, L.; Yang, C.; Yu, L.; Chang, L.; Bu, K. Integrated Use of GCM, RS, and GIS for the Assessment of Hillslope and Gully Erosion in the Mushi River Sub-Catchment, Northeast China. Sustainability 2016, 8, 317. [CrossRef]

69. Meliho, M.; Khattabi, A.; Mhammdi, N. A GIS-Based Approach for Gully Erosion Susceptibility Modelling Using Bivariate Statistics Methods in the Ourika Watershed, Morocco. Environ. Earth Sci. 2018, 77, 655. [CrossRef]

70. Sadiki, A.; Faleh, A.; Zezerze, J.L.; Mastass, H. Quantifcation de l'erosion En Nappe Dans Le Bassin Versant de l'Oued Sahla, Rif Occidental Maroc. Cah. Géogr. 2009, 6, 59-70.

71. Tahiri, M.; Tabyaoui, H.; Tahiri, A.; Hadi, H.E.; Hammichi, F.E.; Achab, M. Modelling Soil Erosion and Sedimentation in the Oued Haricha Sub-Basin (Tahaddart Watershed, Western Rif, Morocco): Risk Assessment. J. Geosci. Environ. Prot. 2016, 4, 107-119. [CrossRef] 